\title{
The Ancestral Caddo Ceramic Assemblage from the D. W. Moye Site (41JP3) on the Angelina River, Jasper County, Texas
}

Timothy K. Perttula

Heritage Research Center, Stephen F. Austin State University

Follow this and additional works at: https://scholarworks.sfasu.edu/ita

Part of the American Material Culture Commons, Archaeological Anthropology Commons, Environmental Studies Commons, Other American Studies Commons, Other Arts and Humanities Commons, Other History of Art, Architecture, and Archaeology Commons, and the United States History Commons

Tell us how this article helped you.

This Article is brought to you for free and open access by the Center for Regional Heritage Research at SFA ScholarWorks. It has been accepted for inclusion in Index of Texas Archaeology: Open Access Gray Literature from the Lone Star State by an authorized editor of SFA ScholarWorks. For more information, please contact cdsscholarworks@sfasu.edu. 


\section{The Ancestral Caddo Ceramic Assemblage from the D. W. Moye Site (41JP3) on the Angelina River, Jasper County, Texas \\ Creative Commons License \\ (c) (1) \&}

This work is licensed under a Creative Commons Attribution-NonCommercial 4.0 International License 


\section{The Ancestral Caddo Ceramic Assemblage from the D. W. Moye Site (41JP3) on the Angelina River, Jasper County, Texas}

Timothy K. Perttula

\section{Introduction}

The D. W. Moye site (41JP3) was recorded by Gus E. Arnold in June 1940 as part of the WPA archaeological survey of East Texas. The site, estimated to cover ca. 2 acres, is located on an alluvial terrace of the Angelina River (Figure 1), at the far southern end of the Caddo archaeological area in the East Texas Pineywoods.

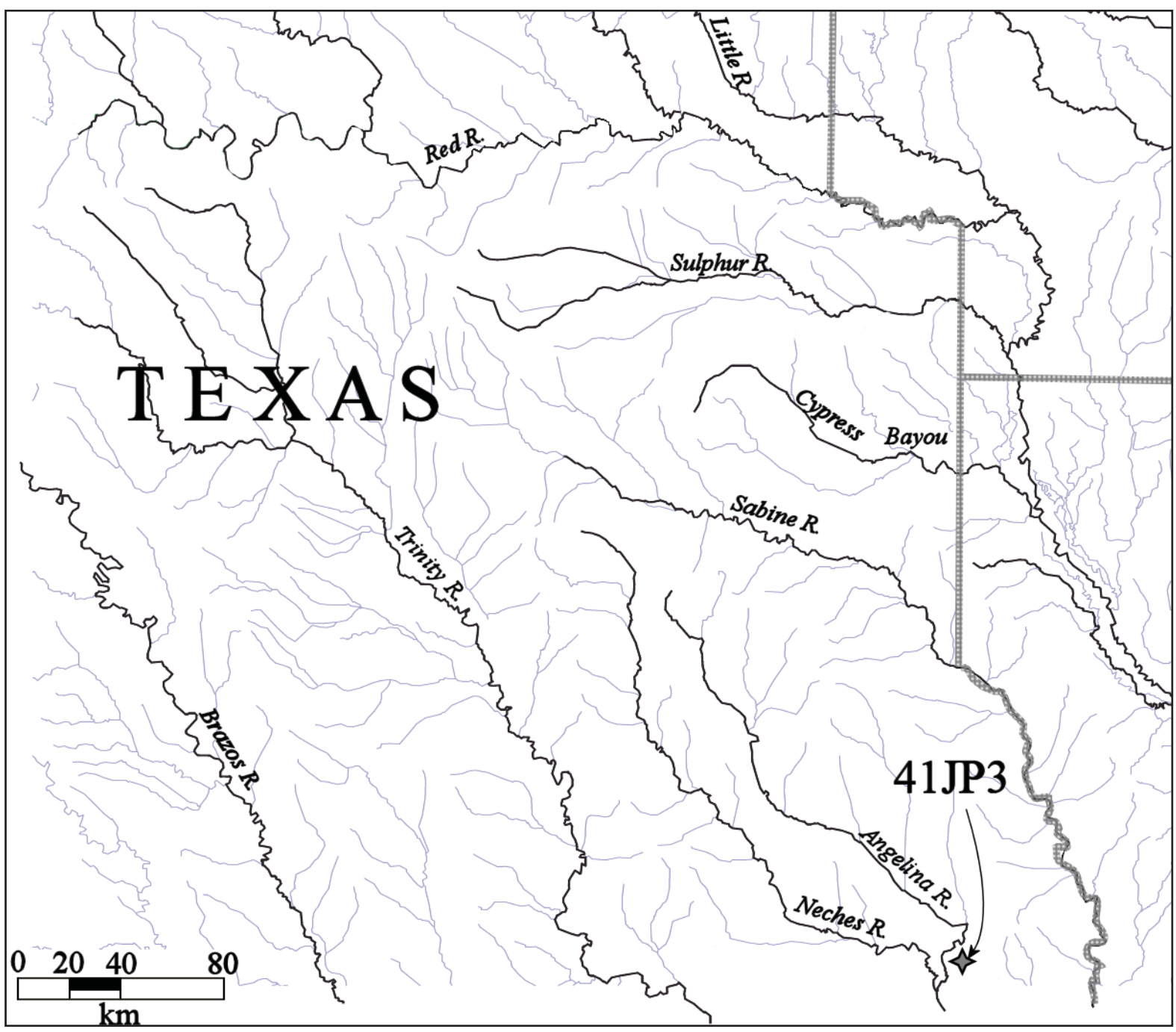

Figure 1. The location of the D. W. Moye site (41JP3) in East Texas. 
During the 1940 archaeological survey of the landform, Arnold collected a substantial sample of ceramic vessel sherds from the surface of the site (see below). He also recovered a few chipped stone tools.

\section{Ceramic Assemblage}

The ceramic assemblage from the D. W. Moye site includes sherds from both Mossy Grove Woodland (see Story 1990; Ellis 2013) and ancestral Caddo occupations. The Mossy Grove ceramics from the site $(n=48)$ are from Goose Creek Plain, var. unspecified sandy paste rim $(n=4)$ and body $(n=44)$ sherds.

The ancestral Caddo ceramic wares include sherds from grog-tempered and bone-tempered vessels, both plain and decorated (Table 1). Approximately 94.3 percent of the sherds are from grog-tempered vessels, and the remaining 5.7 percent are from bone-tempered vessels; 8.2 percent of the plain ware sherds are from bone-tempered vsesels, compared to only 2.9 percent of the utility ware sherds and 5.6 percent of the fine ware vessel sherds.

Table 1. Ancestral Caddo ceramic wares at the D. W. Moye site.

\begin{tabular}{lccc}
\hline Ware & Grog-tempered & Bone-tempered & N \\
\hline Plain & 101 & 9 & 110 \\
Utility & 100 & 3 & 103 \\
Fine & 17 & 1 & 18 \\
\hline Totals & 218 & 13 & 231 \\
\hline
\end{tabular}

There are five rims in the plain wares, seven base sherds, and 98 body sherds; three of the plain body sherds have a single drilled perforation that ranges from 6.0-10.8 $\mathrm{mm}$ in diameter. These perforations were likely employed in suspending vessels over a fire. The plain to decorated sherd ratio in the assemblage is 0.91 , and 83 percent of the decorated sherds are from utility ware vessels (see Table 1). Other ceramic metric measures for the D. W. Moye assemblage include the brushed/plain sherd ratio of 0.26 and the brushed/other wet paste sherd ratio of 0.39 .

Sherds from utility ware vessels with incised decorative elements comprise approximately 50 percent of the decorated sherds in the D. W. Moye site assemblage (Table 2). Another 28 percent of the decorated sherds have brushed and brushed-incised decorative elements, followed by punctated ( 15.5 percent), incised-punctated (4.9 percent), and grooved (1.9 percent). Only 12.5 percent of the decorated sherds are from engraved vessels, and 4.9 percent are from vessels with trailed decorative elements.

Table 2. Decorative methods and elements in the ancestral Caddo ceramic assemblage from the D. W. Moye site.

Decorative method/

Rim Body $\mathrm{N}$

Decorative element

\section{Utility Ware}

\section{Brushed}

horizontal brushed

parallel brushed

vertical brushed

$\begin{array}{lll}- & 2 & 2 \\ - & 25 & 25 \\ 1 & - & 1\end{array}$


Table 2. Decorative methods and elements in the ancestral Caddo ceramic assemblage from the D. W. Moye site.

\begin{tabular}{|c|c|c|c|}
\hline $\begin{array}{l}\text { Decorative method/ } \\
\text { Decorative element }\end{array}$ & Rim & Body & $\mathrm{N}$ \\
\hline
\end{tabular}

\section{Utility Ware, cont.}

\section{Brushed-Incised}

vertical incised lines above horizontal brushing marks

\section{Grooved}

straight grooved lines

\section{Incised}

diagonal incised lines

diagonal opposed incised lines

horizontal incised lines

opposed incised lines

parallel incised lines

straight incised line

vertical incised lines

\section{Incised-Punctated}

curvilinear incised zone and tool punctated rows curvilinear incised line and adjacent tool punctated zone horizontal and diagonal incised lines, and curvilinear incised zone with circular punctations

straight incised line and adjacent tool punctated zone

$\begin{array}{lll}3 & 1 & 4 \\ - & 4 & 4 \\ 4 & - & 4 \\ - & 5 & 5 \\ - & 28 & 28 \\ - & 4 & 4 \\ - & 2 & 2\end{array}$

\section{Punctated}

fingernail punctated rows

linear tool punctated rows

tool punctated rows

$\begin{array}{lll}1 & - & 1 \\ - & 2 & 2 \\ 1 & - & 1 \\ - & 1 & 1 \\ & & \\ - & 11 & 11 \\ - & 2 & 2 \\ 1 & 2 & 3\end{array}$

\section{Fine Ware}

\section{Engraved}

concentric circle engraved el.

cross-hatched engraved zone

curvilinear and diagonal engraved lines, and excised

triangle on curvilinear line

diagonal engraved lines

excised bracket and zone

horizontal and diagonal engraved lines

parallel engraved lines

parallel and opposed engraved lines

rectilinear hatched engraved zone

straight engraved line

vertical and concentric semi-circle engraved lines

and excised semi-circle 
Table 2. Decorative methods and elements in the ancestral Caddo ceramic assemblage from the D. W. Moye site, cont.

\begin{tabular}{lll}
\hline $\begin{array}{l}\text { Decorative method/ } \\
\text { Decorative element }\end{array}$ & Rim & Body \\
\hline
\end{tabular}

Fine Ware, cont.

Trailed horizontal and circular trailed lines parallel trailed lines straight trailed line

\begin{tabular}{lll}
- & 1 & 1 \\
- & 3 & 3 \\
- & 1 & 1 \\
\hline 14 & 107 & 121
\end{tabular}

Totals

The two grooved sherds in the assemblage are from Lindsey Grooved jars. Lindsey Grooved is an Historic Caddo Allen phase utility ware type comprised of large bowls or jars with direct or slightly everted rims. The rims have shallow horizontal grooves (Marceaux 2011:140-141). Lindsey Grooved vessels also occur in conjunction with appliqued, brushed, incised, or punctated elements, typically either at the rim-body juncture or on the vessel body.

The most distinctive of the sherds from incised vessels have diagonal opposed decorative elements (Figure 2a), similar to Maydelle Incised vessels, and sherds with nested diagonal opposed incised elements (Figure 2b). The sherds with incised-punctated decorative elements are likely from Pineland Punctated-Incised jars, as they have concentric, triangular, rectangular, and curvilinear incised zones on the rim filled with tool punctations (Figure 2c-d). Ollas and bowls have design elements on the vessel bodies (see Jelks 1965:Figure 61d, g). At Lake Sam Rayburn sites on the Angelina River, Pineland PunctatedIncised sherds and vessels occur in both Middle Caddo (ca. A.D. 1200-1400/1450) and Late Caddo (ca. A.D. 1400/1450-1680) contexts. Based on analyses by Perttula and Walters (2016), incised-punctated utility wares are most abundant in later Middle Caddo period components estimated to date from ca. A.D. 1300-1400/1450, and least common in post-A.D. 1400/1450 Late Caddo period components.

The punctated sherds are from vessels that have rows of either fingernail or tool punctations (see Table 2). These punctations occur on the rim, and likely the upper body, of jars.

Among the fine wares, two sherds are from King Engraved vessels (Figure 3d). King Engraved is an Allen phase fine ware found in ceramic assemblages in the Angelina River basin. Decorative elements include cross-hatched engraved zones, either in panels, in panel dividers, or in large bands oriented in several directions on the rim (Marceaux 2011:154). Other engraved sherds have geometric decorative elements, including diagonal lines and parallel and opposed lines (Figure 3a), as well as hatched engraved zones and concentric circles.

One rim sherd in the assemblage has diagonal and curvilinear engraved elements, with a large excised pendant triangle on the curvilinear line (see Figure 3c), while another has a broad excised bracket. The most distinctive engraved sherd has vertical and concentric circle elements around an excised semi-circle (see Figure 3b). This sherd is from a Holly Fine Engraved vessel (see Suhm and Jelks 1962:Plates 39f, h and 40e).

Five sherds have trailed decorative elements (see Figure 3e), including parallel trailed lines and circular and horizontal trailed lines. These sherds are likely from Keno Trailed vessels. 


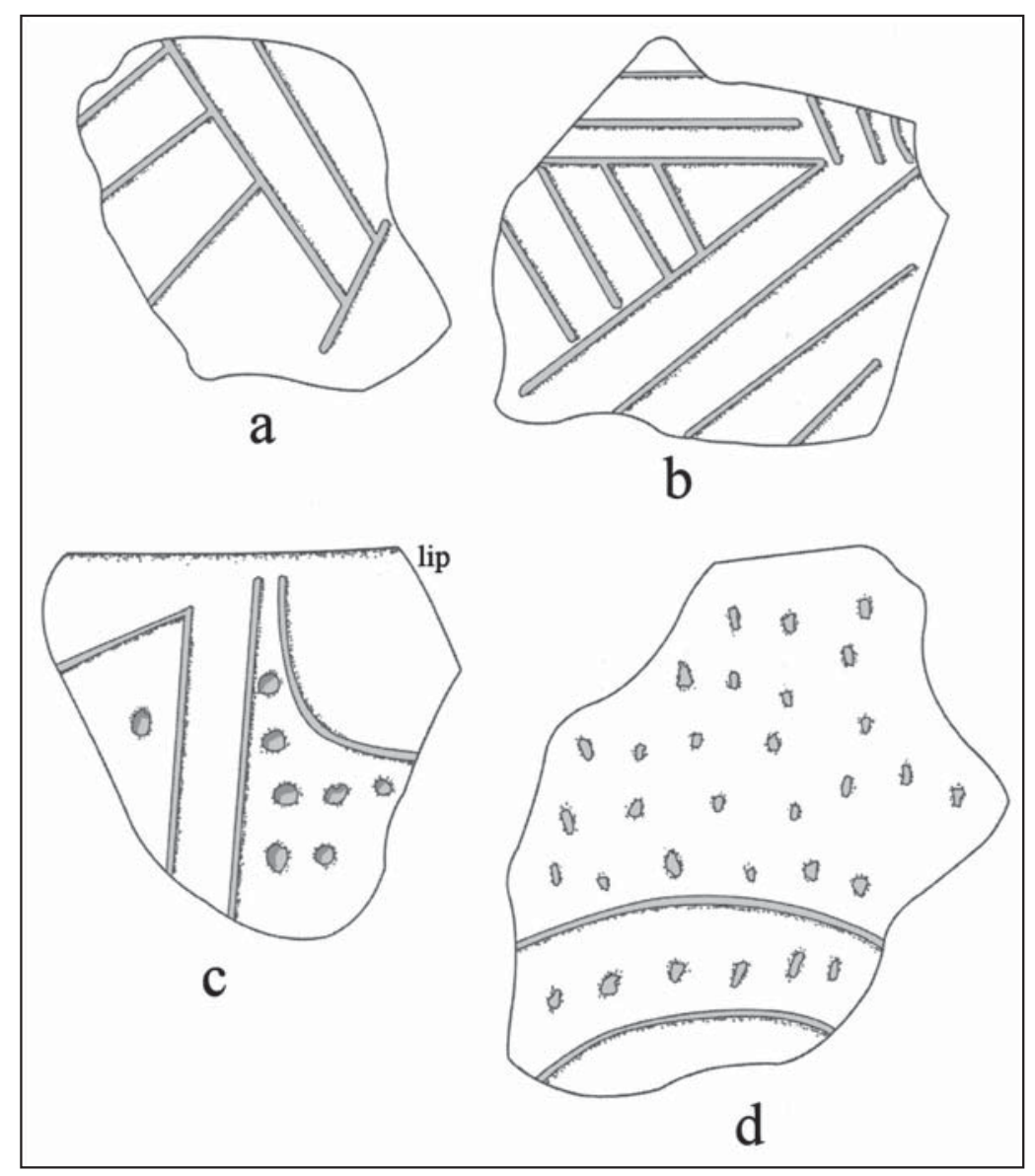

Figure 2. Selected decorative elements on utility ware sherds from the D. W. Moye site: a-b, incised; c-d, incised-punctated.

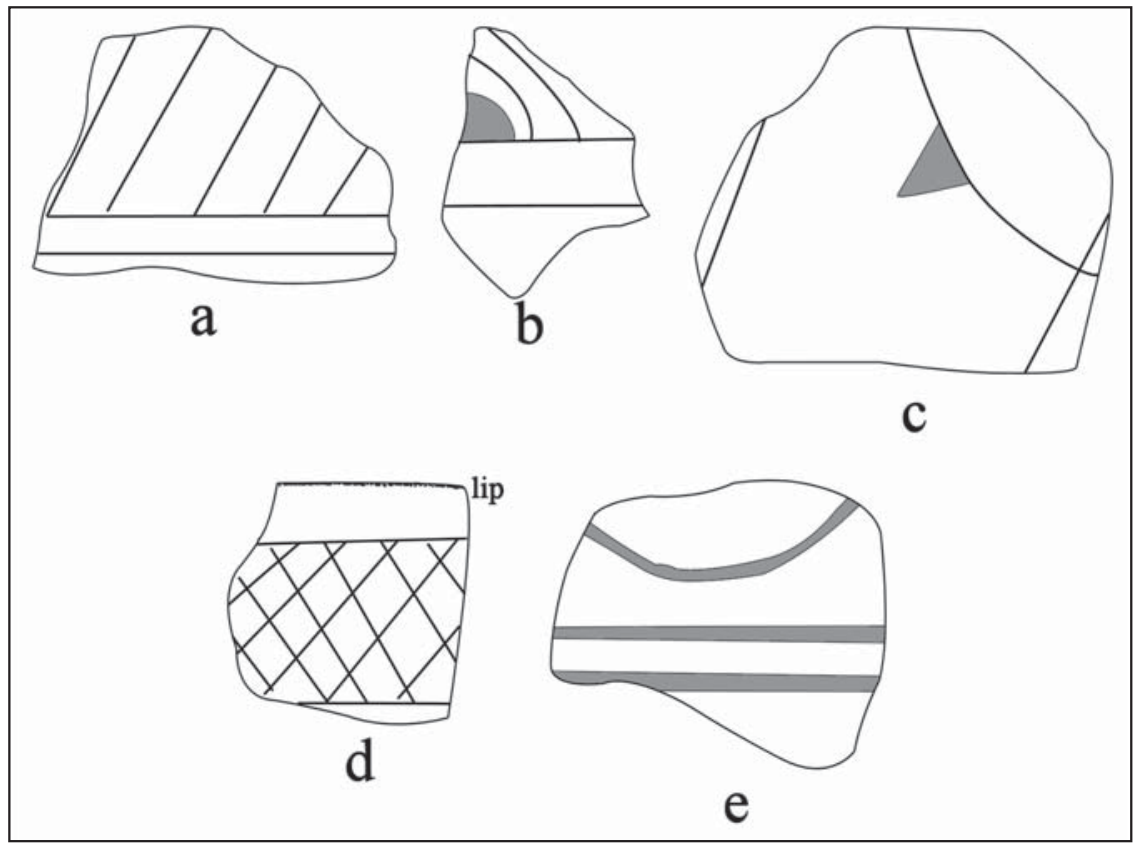

Figure 3. Selected decorative elements on fine ware sherds from the D. W. Moye site: a-d, engraved; e, trailed. 


\section{Lithic Assemblage}

Arnold collected fragments of two arrow points from the D. W. Moye site. The first is a red chert blade fragment, and the second is a parallel-stemmed form, probably an Alba point, made from a local brown chert. The blade on this point has been serrated and resharpened.

\section{Summary and Conclusions}

The D. W. Moye site (41JP3) was recorded by Gus Arnold in June 1940, during the course of the WPA-sponsored archaeological survey of East Texas. The site is on an alluvial terrace of the Angelina River in the southernmost part of the Caddo archaeological area in East Texas.

Arnold collected a wide variety of ceramic vessel sherds $(n=279)$ from the plowed surface of the site. About 17 percent are sandy paste Goose Creek Plain, var. unspecified sherds from a Mossy Grove (ca. 500 B.C.-A.D. 800) occupation. The remainder of the sherds are from ancestral Caddo occupations. Galan (2003) described another assemblage of ancestral Caddo sherds, with brushed decorative elements, from 41JP154 in the Neches River basin at Lake Steinhagen.

The one Holly Fine Engraved sherd in the collection and a few other engraved sherds with diagonal opposed and concentric circle elements indicate that the D. W. Moye site was first used during the Early Caddo period (ca. A.D. 1000-1200), but the principal Caddo occupation likely took place well after ca. A.D. 1300, perhaps mainly after ca. A.D. 1650. Historic Allen phase ceramics in the D. W. Moye site assemblage include sherds from Lindsey Grooved and King Engraved vessels, and the presence of several likely Keno Trailed sherds is also indicative of a post-A.D. 1650 age. The character of the utility wares from the site, especially the proportion of brushed sherds in the assemblage ( 28.2 percent), its brushed/ plain sherd ratio of 0.26 , and a brushed/other wet paste sherd ratio of 0.39 , are much like the Historic Caddo Attoyac Bayou cluster of sites in the Angelina River basin (Perttula 2016:Table 4). The Attoyac cluster (Group VIII) has much lower proportions of brushed sherds (30.4 percent) and more equitable brushed to other wet paste sherd ratios (0.61) than other groups of Historic Caddo sites that have been confidently linked to the Hasinai Caddo, but these metrics are not far different from the D. W. Moye site assemblage. The ethnic affiliation of this group of sites in the Attoyac Bayou basin, and the lower Angelina river, is not known.

\section{Acknowledgments}

Thanks to Marybeth Tomka for access to the collections from the D. W. Moye site held by the Texas Archeological Research Laboratory at The University of Texas at Austin. Lance Trask prepared the figures in this article.

\section{References Cited}

Ellis, L. W.

2013 Woodland Ceramics in East Texas and a Case Study of Mill Creek Culture Ceramics. Bulletin of the Texas Archeological Society 84:137-180.

Galan, V.

2003 Prehistoric Ceramic Analysis. In A Cultural Resource Inventory of Selected Areas at Lake Sam Rayburn and Town Bluff Dam/Steinhagen Lake, Texas, by W. N. Trierweiler and M. L. Bonine, pp. A-1 to A-3. Report 04602. Ecological Communications Corporation, Austin. 
Jelks, E. B.

1965 The Archeology of McGee Bend Reservoir, Texas. Ph.D. dissertation, Department of Anthropology, The University of Texas at Austin.

Marceaux, P. S.

2011 The Archaeology and Ethnohistory of the Hasinai Caddo: Material Culture and the Course of European Contact. Ph.D. dissertation, Department of Anthropology, The University of Texas at Austin.

Perttula, T. K.

2016 Utility Ware Ceramic Metrics and Hasinai Caddo Archaeology in East Texas. Journal of Northeast Texas Archaeology 70:61-68.

Perttula, T. K. and M. Walters

2016 Incised-Punctated Utility Ware Sherds from Lake Sam Rayburn Ancestral Caddo Sites. Journal of Northeast Texas Archaeology 62:1-18.

Story, D. A.

1990 Cultural History of the Native Americans. In The Archeology and Bioarcheology of the Gulf Coastal Plain, by D. A. Story, J. A Guy, B. A. Burnett, M. D. Freeman, J. C. Rose, D. G. Steele, B. W. Olive, and K. J. Reinhard, pp. 163-366. Research Series No. 38. 2 Vols. Arkansas Archeological Survey, Fayetteville.

Suhm, D. A. and E. B. Jelks (editors)

1962 Handbook of Texas Archeology: Type Descriptions. Special Publication No. 1, Texas Archeological Society, and Bulletin No. 4, Texas Memorial Museum, Austin. Reprinted in 2009, Gustav's Library, Davenport, Iowa. 